Vol. 1, No. 1, 2020

Oleh Hrytsun, Oleksii Lanets, Serhiy Solodkyy

Lviv Polytechnic National University

Bandery Str. 12, Lviv, Ukraine, 79000

(C) Hrytsun O., Lanets O., Solodkyy S., 2020

https://doi.org/10.23939/tt2020.01.033

\title{
IMPACT OF STREET PARKING ON DELAYS AND THE AVERAGE SPEED OF TRAFFIC FLOW
}

\begin{abstract}
Summary. The article is devoted to the problem of the impact of street parking on delays and the average speed of traffic flow. The sections with different ways of putting vehicles near the roadway in the central part of Lviv city with the most saturated flow were exposed to scientific scrutiny. For this purpose, the program software PTV Vissim is used. The causes of the impact of street parking on traffic flow speed and roadway capacity are analyzed. Simulation model was created, with the use of which the operation of the street section where parking is allowed and without parking, and also the impact of the parking duration on the average speed of traffic flow and its delays were investigated. It is clarified that the least values the average traffic delay has with the parking duration of 900 and $1800 \mathrm{sec}$, and the biggest values it has with the duration of $300 \mathrm{sec}$. It is determined that during the street parking design parallel to the sidewalk it is necessary to implement the restriction of the parking duration to increase the road network capacity and traffic flow speed.

Key words: road network, traffic flow, traffic intensity, speed of movement, capacity, roadcapacity ratio, traffic simulation, field research, queue length, traffic delays.
\end{abstract}

\section{INTRODUCTION}

The alongside parking in the central part of the cities is the usual situation. It creates an obstacle for public transport, special service vehicles, street cleaning, etc. Car parking near the roadway decreases the street capacity by $20-40 \%$, reduces the average speed of traffic flow movement that passes these sections, increases the probability of accidents. It can be explained by the fact that the area, occupied by parking vehicles, exceeds the area of city streets and roads used for traffic flow movement.

\section{RESEARCH STATEMENT}

In recent years, with motorization growth, the problem of automobile transport parking became extremely important in Ukraine. Car parking on the city road network is a complicated problem as with the growth of motorization level the need in the parking space increases. At the same time, the number of vehicles on the road network increases, which makes it impossible to increase the parking space, but, on the contrary, is the condition for its reduction. As a result, it is necessary to increase the capacity of city streets, which in terms of existing building can only be achieved by organizational methods.

\section{RELEVANCE OF THE STUDY}

One of the ways of solving the problem of congestion of the city road network in the conditions of growth of the car fleet and the volume of transportation is to increase the efficiency of its use by developing and theoretically justifying new, more objective approaches to solving the problem of increasing the capacity in the areas of intensive car parking. Such control should meet requirement for road users, proceeding from the two main motion objective functions - the speed and the capacity. 


\section{FORMULATION OF THE AIM AND TASK OF THE RESEARCH}

The main aim of the publication is to simulate the impact of street parking on the change of traffic flow characteristics in the area of sections between intersections. For this purpose, it is necessary to have a great amount of data, gathered by field research. Conducting such research is a time-consuming process and requires a lot of measurements on the big number of road network sections of unequal length with different traffic flow composition and variable movement conditions. Change of the length is needed for investigation of the period of traffic flow structuration, traffic flow composition - for the evaluation of the impact of vehicle external dimensions, and variability of conditions - for the analysis of traffic flow movement dynamics.

To achieve the aim, such tasks are formulated:

- to analyze the regularities and the main methods of investigation of street parking influence on the capacity of the road network;

- to carry out field research on the change of changes in traffic flow indicators considering the impact of street parking;

- to investigate the impact of the duration of parking on the average velocity of traffic flow and its delays.

\section{ANALYSIS OF THE RECENT RESEARCH AND PUBLICATIONS}

A lot of approaches to the parking organization and its impact on traffic flows movement conditions are known in theory and practice. Especially acute this problem is at intersection zones: at uncontrolled intersections, it is expressed via limitation of visibility zones; at controlled intersections - via reduction of saturation flows. Parked vehicles on sections between intersections cause the sharp decrease of capacity due to the formation of numerous zones of flow interweaving, when vehicles moving on the right lane are forced to maneuver due to obstruction on it [3-5]. The traffic managers should pay special attention to locations of pulling into and out of parking lots. Although, a lot of these aspects are specified in the regulatory documents, they do not provide an answer for the extent of such a negative impact [6].

In recent years, the question of the dependence of the traffic flow effectiveness from parking parameters in cities has been investigated very widely. Deep theoretical research of V. Polishchuk [1], O. Lobashov [8] can be admitted. The question of transport movement organization in the modern city is being considered in great detail in the works of E. Gavrilov [9], H. Valylieva [10] and others.

An important characteristic of street parking is the scheme of vehicle location as it depends on the complexity and the duration of pulling into and out and, respectively, the speed and delays of the main flow depend on it $[6,7,11]$.

Control of street parking regime is also an important component for traffic flow regulation that move towards the central part of the city, as a rule, with high population density [3]. A range of measures can be taken for regulation of the regime of stopping and parking: stopping restriction, restriction with time limitation; regulation of vehicle location on the parking; local regulation of the regime of stopping and parking; paid parking. Using street parking bans can reduce road accidents by $20-25 \%$ [3, 12]. However, it should be taken into account that imposing a parking ban on one street will inevitably shift the parking on other streets, on which it is impossible to avoid accidents with injury and material damage.

Organization of vehicle parking without considering street capacity causes movement complications, hence, the negative impact on the environment [13].

When solving city parking problems, street parking is important. However, its main disadvantage is the negative impact on the road network capacity. That is why the main criterion of such a parking type should be the determination of the impact of street parking on the road network capacity $[5,7,13-15]$.

A lot of factors have an influence on the road network capacity value: road conditions (roadway width, longitude inclination, horizontal curve radius, clear vision distance, etc.); traffic flow composition; availability of control means, weather conditions; the possibility of vehicle maneuvering on the roadway width; presence (or absence) of parking zones; psychophysiological properties of the driver. The change of 
these factors significantly affect the capacity fluctuation during the day, month, season and year. In conditions of frequent irregularities on the road, a significant fluctuation of the speed occurs, as a result, traffic delay increases and road network capacity decreases [5, 7, 15-18]. As a result, the number of road accidents increases, and also the ecological, social and economic problems appear.

To evaluate the impact of street parking on the road network capacity, it is necessary to use an approach that considers parking with different car positions on the roadway [11]. The reduction of the capacity occurs because of traffic flow speed reduction which is the main characteristic of traffic and in many respects determines the effectiveness of the road network. Theoretical capacity of the roadway is the function of speed $A=f(v)[1,2]$ :

$$
P=\frac{3600 \cdot v}{(l+2)+v+0,13 \cdot v^{2}} \cdot \eta
$$

where $v$ - vehicle speed, $\mathrm{km} / \mathrm{h} ; l$ - vehicle length, $\mathrm{m} ; \eta$ - number of lanes.

$$
\eta=\sum B_{i}
$$

where $B_{i}-$ coefficient of lane capacity use, the value of which is: for the first free lane -1 , for the second -0.85 , for the next -0.5 .

In the case of location of vehicles along the roadway, the capacity calculates $[1,2,13]$ :

$$
P=\frac{3600 \cdot v}{(l+2)+v(1-V)+0,13 \cdot v^{2}} \cdot \eta(1-B),
$$

where $V$ - speed of merging the vehicle into the main flow from the sidewalk, $\mathrm{km} / \mathrm{h} ; B$ - coefficient of the reduction of the roadway width.

$$
B=\frac{B_{R W . e f}}{B_{R W}},
$$

where $B_{R W . e f}$ - effective roadway width, $\mathrm{m} ; B_{R W}$ - roadway width, $\mathrm{m}$.

If vehicles are located under the angle to the roadway, then the capacity will change due to the change of $B[1,2]$ :

$$
B=\frac{\left(l_{0} \cdot \sin \alpha+b \cdot \cos \alpha\right)+1,1}{B_{R W}},
$$

where $l_{0}$ - vehicle length, $\mathrm{m} ; \alpha$ - the angle of vehicle location to the roadway, deg; $b$ - vehicle width, $\mathrm{m}$

To create the models of the impact of street parking on delays and the average speed of traffic flow, it is necessary to take into account a lot of factors - arrival time of vehicles to the parking, time of staying on the parking, intensity of the arrival, parking capacity, queue length, etc. Besides, it is also necessary to consider a range of additional factors - parking fee, information on the degree of occupancy of the parking lot, the existence of public transport routes $[10,14,15]$. Almost all these parameters change randomly. Therefore, simulation modeling should be used to build predictive models [8].

The analysis of special literature [18] showed that experts from different countries in the process of formation the travel demand consider parking as a severe restriction (number of trips in a certain district depends on the general number of parking lots in considered district). These two guidelines are fundamental in developing models that concern the parking system.

To develop such models, it is necessary to know the parameters of traffic flow arrival distribution, service time, parking lots occupancy, queue length, waiting time. Almost all techniques and methods use the assumption that vehicle arrival to the parking is the subject of Poisson distribution, and the duration of parking is described by the negative exponential distribution. After that, the general model of multichannel arrival and parking system is usually used. In conditions of one arrival to the parking, all vehicles are in one queue and move to the moment of vacancy. The main equations that allow calculating the queue length $\left(L_{q}\right)$ are [18]: 


$$
L_{q}=\frac{\rho}{\left(n_{p}-1\right) !\left(n_{p}-\rho\right)^{2}} \cdot P_{0}
$$

where $\rho=\frac{\mu}{N}$ - the ratio of the average parking time to the entrance flow intensity; $n_{p}$ - number of parking lots; $P_{0}$ - the probability of the absence of the vehicle on the parking lot.

Analysis of the given method of modeling the parking processes shows that independence of the main parameters for parking - the moment when vehicles are parking and leaving the parking lot, duration of parking and the number of occupied lots - are not taken into account. Therefore, the following approach can be applied when investigating the impact of the parking on delays and average speed of traffic flow. The development of simulation model should be carried out in specialized software product PTV VISSIM, which can be used to investigate the functioning of the street section with allowed parking and its absence, as well as the impact of parking duration on the average speed of traffic flow and its delays [8].

\section{RESEARCH ON THE IMPACT OF STREET PARKING ON TRAFFIC FLOW DELAYS}

The research of the impact of street parking on traffic flow delays requires processing a large amount of arrays of input data (intensity of vehicle arrival, speed of movement, parking time, etc.) [2, 9, 19].

To investigate the impact of street parking on delays and the average speed of traffic flow, sections with different ways of parking in the central part of Lviv city with the most saturated traffic movement were chosen. Research was carried out on city-wide streets with controlled motion, as they were slowing down mostly because of parked cars near the roadway.

The first investigated section is Kovzhuna St., which is located in the Halytskyi district of Lviv and connects Voronoho St. and Dudaieva St. The way of parking is parallel to the sidewalk. Planning situation: roadway width is $7.0 \mathrm{~m}$; the number of lanes is one; the pavement is cobblestone; longitude inclination is $5 \%$.

The next investigated section is Shpytalna St., which is located in the Halytskyi district of Lviv and connects Horodotska St. and Sholom-Aleikhema St. The way of parking is under the angle of $30^{\circ}$ to the sidewalk and the angle of $90^{\circ}$ to the sidewalk. Planning situation: roadway width is $16,0 \mathrm{~m}$; the number of lanes is 3; the pavement is cobblestone; longitude inclination is $5 \%$.

The third investigated section is Kopernyka St. The way of parking is laied out under the angle of $45^{\circ}$ to the sidewalk. Kopernyka St. is in the Halytskyi district of the city and connects Stepana Bandery St. and Svobody Av. Planning situation: roadway width is $10.0 \mathrm{~m}$; the number of lanes is 2; the pavement is cobblestone; longitude inclination is $25 \%$.

The last investigated way of parking under the angle of $60^{\circ}$ to the pavement is on Shevchenka Av. Shevchenka Av. is one of the central streets of Lviv and connects Saksahanskoho St. and Mitskevycha Sq. Administratively belongs to Halytskyi district of the city. Planning situation: roadway width is $9.0 \mathrm{~m}$; the number of lanes is two; the pavement is cobblestone; longitude inclination is $10 \%$.

When processing the results of field research, at first, it is necessary to obtain iformation about the primary characteristics of the traffic flow (intensity, speed, and density). To estimate the necessary information about traffic flow characteristics, the selective accounting of movement in short periods of time (one hour) can be used. Information by one hour allows obtaining the subjective information about traffic flow delays in the zone of street parking impact. Justification of the minimal number of observations for the determination of traffic delay in the zone of parking impact is calculated by equation $[1,2,8,10]$ :

$$
n=\frac{t_{\alpha} \cdot \sigma^{2}}{\zeta^{2}}
$$

where $n$ - number of observations; $t_{\alpha}$ - function of confidence figure (under the value $\zeta=0.1$, the function of confidence figure is $\left.t_{\alpha}=1.28\right) ; \sigma$ - mean square deviation $(\sigma=0.12) ; \zeta$ - maximum permissible error (we accept in a range $0.05-0.2$ ). 
Using equation (7), let's determine the period during which it is necessary to carry out research:

$$
n=\frac{1.28 \cdot 0.12^{2}}{0.1^{2}}=3.04 \approx 3 .
$$

Therefore, to obtain credible information about delays and traffic flow speed on the network sections, it is necessary to carry out three observations by the duration in one hour. The time of the survey is from 7 a.m. to 10 a.m.

On weekdays (Tuesday, Wednesday and Thursday) vehicles of different traffic flow composition were fixed. The traffic intensity was determined with the help of passenger car equivalent (in $\mathrm{pcu} / \mathrm{h}$ ). For example, on Shevhenka Av. for Tuesday from 7 a.m. to 8 a.m. the passenger car equivalent intensity is:

$$
N_{\text {Tuesday } 7-8}=1284+47 \cdot 1.5+6 \cdot 2+4 \cdot 2.5+22 \cdot 2.5=1432 \mathrm{pcu} / \mathrm{h} .
$$

Similarly, we calculate passenger car equivalent intensity for other periods of investigation: from 8 a.m to 9 a.m, intensity is $1347 \mathrm{pcu} / \mathrm{h}$; from 9 a.m. to 10 a.m. $-1256 \mathrm{pcu} / \mathrm{h}$.

The average traffic intensity per hour in investigated day is:

$$
\bar{N}_{\text {Tuesday }}=\frac{1432+1347+1256}{3}=1345 \mathrm{pcu} / \mathrm{h} .
$$

For other investigated streets of Lviv, calculations were the same. Results of observation processing are given in Table 1.

The next step should be considering parked vehicles that narrow the roadway width and decrease its capacity. Narrowing the roadway width is calculated by equation $[6,8]$ :

$$
B_{R W . e f}=B_{R W}-B_{\text {park }} \text {, }
$$

where $B_{\text {park }}$ - roadway width that is occupied by a parked vehicle near the sidewalk, $\mathrm{m}$.

Values of $B_{\text {park }}$ depending on the ways of parking near the sidewalk are given in Table 2.

Table 1

The average traffic flow intensity in study days

\begin{tabular}{|c|c|c|c|c|c|c|}
\hline \multirow{2}{*}{ Street name } & \multirow{2}{*}{$\begin{array}{c}\text { Number of } \\
\text { lanes }\end{array}$} & $\begin{array}{c}\text { Ways of parking } \\
\text { near the roadway }\end{array}$ & \multicolumn{2}{|c|}{ Traffic intensity, pcu/h } & $\begin{array}{c}\text { The average traffic } \\
\text { intensity per hour, } \\
\text { pcu/h }\end{array}$ \\
\hline Kovzhuna & 1 & $\begin{array}{c}\text { Parallel to the } \\
\text { sidewalk }\end{array}$ & 985 & 1047 & 993 & 1008 \\
\hline Shpytalna & 3 & $\begin{array}{c}\text { Under the angle of } \\
30^{\circ} \text { to the sidewalk }\end{array}$ & 1676 & 1644 & 1589 & 1636 \\
\hline Kopernyka & 2 & $\begin{array}{c}\text { Under the angle of } \\
45^{\circ} \text { to the sidewalk }\end{array}$ & 1789 & 1584 & 1697 & 1690 \\
\hline $\begin{array}{c}\text { Shevchenka } \\
\text { Av. }\end{array}$ & 2 & $\begin{array}{c}\text { Under the angle of } \\
60^{\circ} \text { to the sidewalk }\end{array}$ & 1345 & 1569 & 1532 & 1482 \\
\hline Shpytalna & 3 & $\begin{array}{c}\text { Under the angle of } \\
90^{\circ} \text { to the sidewalk }\end{array}$ & 1676 & 1644 & 1589 & 1636 \\
\hline
\end{tabular}

Having determined the effective roadway width, we calculated the reduction of capacity depending on the ways of parking near the roadway. Using equation (3) and (5), we obtained the results of calculation of the capacity depending on the ways of parking (Table 3 ). 
Values of $B_{\text {park }}$ depending on the ways of parking near the sidewalk $[6,8]$

\begin{tabular}{|c|c|}
\hline The way of parking & $\begin{array}{c}\text { Roadway width that is occupied by parked vehicles near the } \\
\text { sidewalk, } B_{\text {park }}, \mathrm{m}\end{array}$ \\
\hline Parallel to the sidewalk & 2.0 \\
\hline Under the angle of $30^{\circ}$ to the sidewalk & 4.3 \\
\hline Under the angle of $45^{\circ}$ to the sidewalk & 4.8 \\
\hline Under the angle of $60^{\circ}$ to the sidewalk & 5.2 \\
\hline Under the angle of $90^{\circ}$ to the sidewalk & 4.6 \\
\hline
\end{tabular}

Table 3

Determination of the capacity depending on the ways of parking near the roadway

\begin{tabular}{|c|c|c|c|c|c|c|}
\hline Street name & $\begin{array}{c}\text { Number } \\
\text { of lanes }\end{array}$ & $\begin{array}{c}\text { Ways of parking } \\
\text { near the sidewalk }\end{array}$ & $\begin{array}{c}\text { Speed of the } \\
\text { vehicle merging } \\
\text { into the flow, km/h }\end{array}$ & $\begin{array}{c}\text { Coefficient of } \\
\text { roadway } \\
\text { narrowing, } \mathrm{m}\end{array}$ & $\begin{array}{c}\text { Average traffic } \\
\text { intensity per } \\
\text { hour, pcu/h }\end{array}$ & $\begin{array}{c}\text { Street } \\
\text { capacity, } \\
\text { pcu/h }\end{array}$ \\
\hline 1 & 2 & 3 & 4 & 5 & 6 & 7 \\
\hline Kovzhuna & 1 & $\begin{array}{c}\text { Parallel to the } \\
\text { sidewalk }\end{array}$ & 15 & 0.71 & 1008 & 1105 \\
\hline Shpytalna & 3 & $\begin{array}{c}\text { Under the angle of } \\
30^{\circ} \text { to the sidewalk }\end{array}$ & 12 & 0.73 & 1636 & 2057 \\
\hline Kopernyka & 2 & $\begin{array}{c}\text { Under the angle of } \\
45^{\circ} \text { to the sidewalk }\end{array}$ & 9 & 0.52 & 1690 & 1947 \\
\hline $\begin{array}{c}\text { Shevchenka } \\
\text { Av. }\end{array}$ & 2 & $\begin{array}{c}\text { Under the angle of } \\
60^{\circ} \text { to the sidewalk }\end{array}$ & 6 & 0.42 & 1482 & 1948 \\
\hline Shpytalna & 3 & $\begin{array}{c}\text { Under the angle of } \\
90^{\circ} \text { to the sidewalk }\end{array}$ & 4 & 0.71 & 1636 & 2510 \\
\hline
\end{tabular}

Volume-capacity ratio with consideration of street parking is calculated by formula $[6,14]$ :

$$
k_{3}=\frac{N}{\eta \cdot P}
$$

where $N$ - traffic flow intensity on the street, $\mathrm{pcu} / \mathrm{h}$

The values of the volume-capacity ratio for all possible ways of parking near the sidewalk are calculated in Table 4.

Table 4

Values of volume-capacity ration for all possible ways of parking near the sidewalk

\begin{tabular}{|c|c|c|c|c|c|}
\hline Street name & $\begin{array}{c}\text { Number } \\
\text { of lanes }\end{array}$ & $\begin{array}{c}\text { Ways of parking near the } \\
\text { sidewalk }\end{array}$ & $\begin{array}{c}\text { Average traffic } \\
\text { intensity per } \\
\text { hour, pcu/h }\end{array}$ & $\begin{array}{c}\text { Street capacity, } \\
\text { pcu/h }\end{array}$ & $\begin{array}{c}\text { Volume- } \\
\text { capacity } \\
\text { ratio }\end{array}$ \\
\hline Kovzhuna & 1 & Parallel to the sidewalk & 1008 & 1105 & 0.91 \\
\hline Shpytalna & 2 & $\begin{array}{c}\text { Under the angle of } 30^{\circ} \text { to } \\
\text { the sidewalk }\end{array}$ & 1636 & 2057 & 0.80 \\
\hline Kopernyka & 3 & $\begin{array}{c}\text { Under the angle of } 45^{\circ} \text { to } \\
\text { the sidewalk }\end{array}$ & 1690 & 1947 & 0.87 \\
\hline $\begin{array}{c}\text { Shevchenka } \\
\text { Av. }\end{array}$ & 2 & $\begin{array}{c}\text { Under the angle of } 60^{\circ} \text { to } \\
\text { the sidewalk }\end{array}$ & 1482 & 1948 & 0.76 \\
\hline Shpytalna & 3 & $\begin{array}{c}\text { Under the angle of } 90^{\circ} \text { to } \\
\text { the sidewalk }\end{array}$ & 1636 & 2510 & 0.65 \\
\hline
\end{tabular}


From the above values of Table 4, we can conclude that the greatest value of the effect of street parking on the capacity reduction is observed on one-lane streets and it is 0.91 (volume-capacity ratio D). Further simulation of traffic flow with consideration of street parking will allow to compare the results of the field research and make appropriate conclusions under the change of other indicators (traffic flow intensity).

The main question of traffic flow simulation in cities is the investigation of the impact of car parking on indicators of the effectiveness of sections functioning. Let's investigate the change of these indicators under the different ways of parking near the sidewalk. Under the indicator of traffic flow functioning is the indicator that provides a minimum loss of time for travelling (traffic delay), taking into account the actual indicators (traffic flow intensity, speed of merging the vehicles into traffic flow, section capacity, number of lanes) $[6,12]$.

During the investigation of the change of traffic flow parameters considering the impact of street parking, the simulation was carried out in the program software PTV VISSIM. Results of field research under the different ways of parking were taken into account. For the investigation of traffic delays, we changed a volume-capacity ratio from 0 to 1.0. Simulation results are given in Fig. 1.

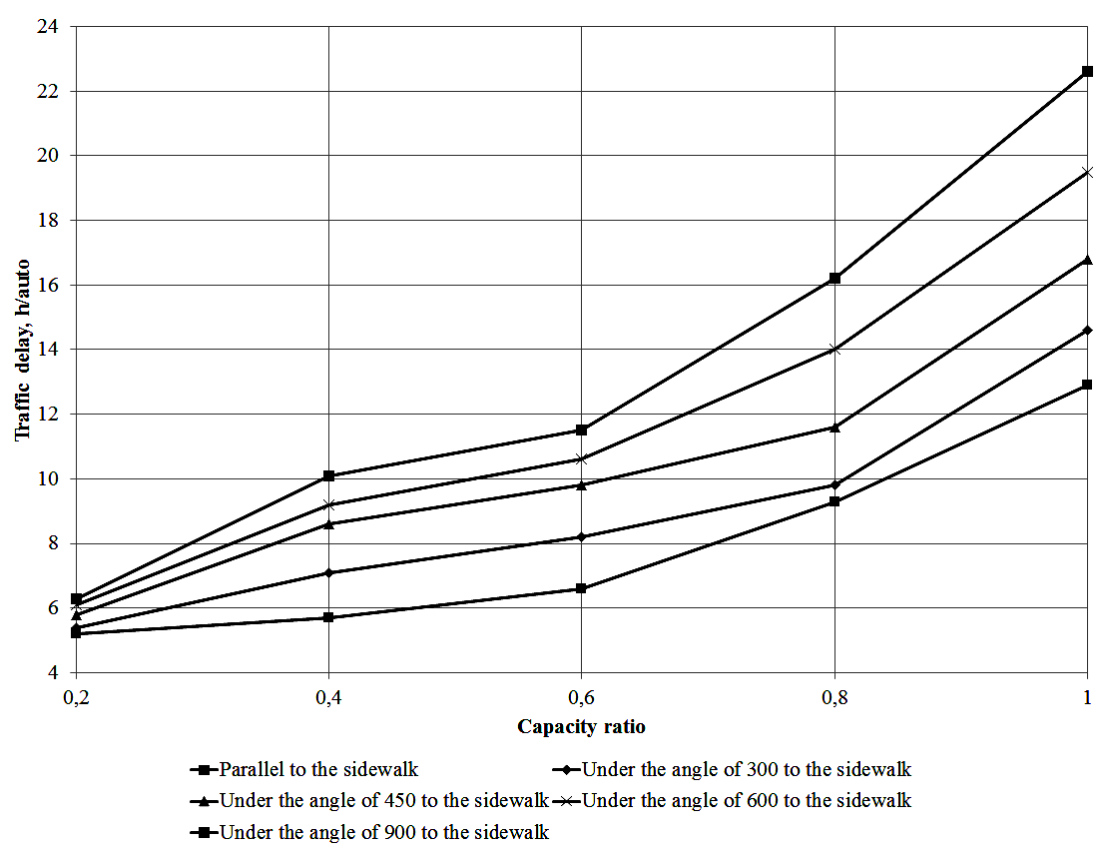

Fig. 1. The graph of change in traffic delays under the different ways of parking with the increase of street volume-capacity ratio

Thereby, the least traffic delay is observed when parking the vehicles parallel to the sidewalk because it is a convenient departure (high speed of merging into the main traffic). We can see from Fig. 1 that with volume-capacity ratio more than 0.8 traffic delay sharply increases as intervals between vehicles are dense and it is difficult for vehicles to merge into the main traffic.

Simulation of the change of volume-capacity coefficient under the different way of parking allowed obtaining the indicators of traffic flow functioning (based on the analysis of the street capacity).

The increase of traffic flow intensity causes such negative consequences as the reduction of traffic flow speed, as a result, road network capacity decreases. That is why the research on the impact of street parking on the traffic flow speed stays the urgent task. With enough information about the regularities of the impact of street parking on the geometric parameters of the road network and traffic flow characteristics, the expediency (or restriction) of their implementation can be justified.

Traffic flow simulation was carried out to compare different vehicle speed under the different ways of parking and also without parking. Simulation results are given in Fig. 2. 


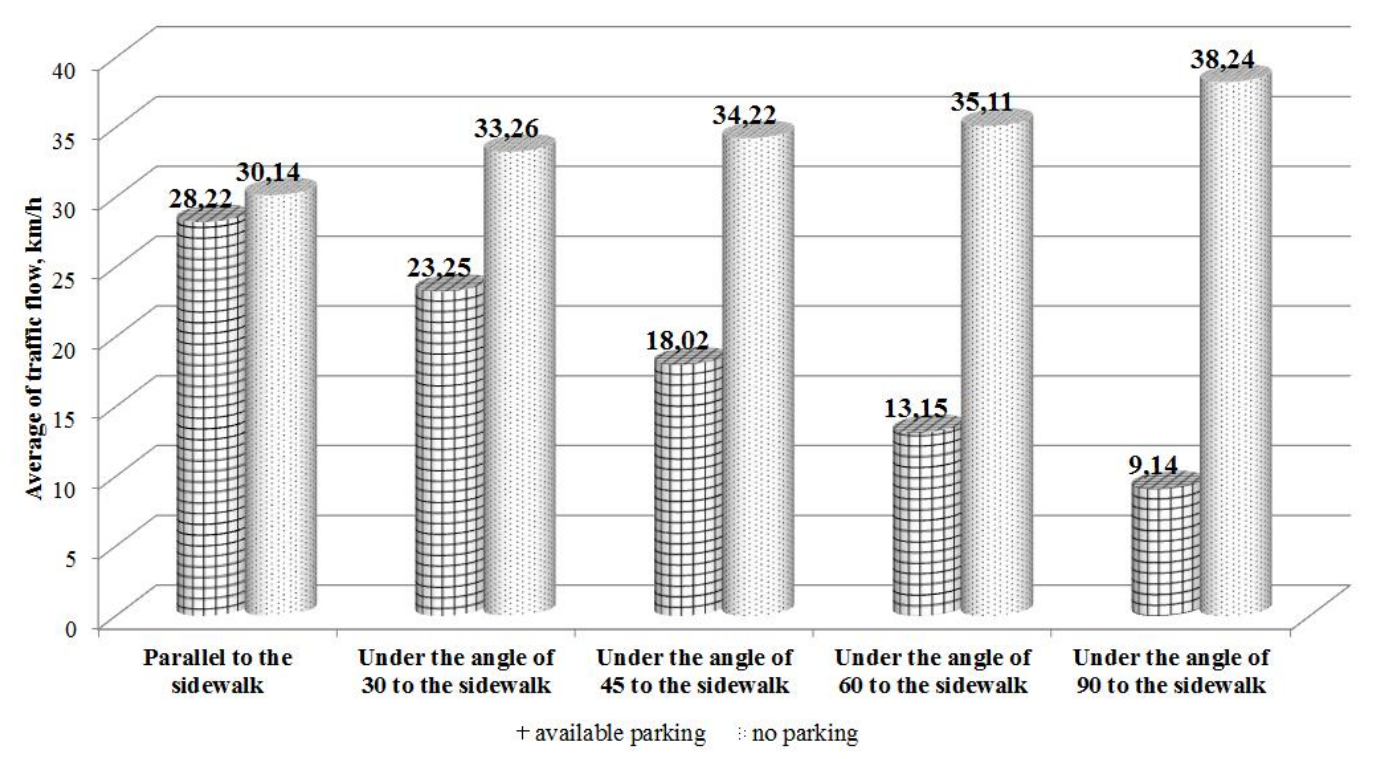

Fig. 2. Histogram of the change of the average speed of traffic flow with and without parking

Analyzing Fig. 2, we can see the linear dependence of the increase of the average speed of traffic flow without parking. The biggest speed is under the restriction of parking under the angle of $90^{\circ}$ to the sidewalk. It can be explained by the fact that it is necessary to allocate the roadway width of $4.6 \mathrm{~m}$. for such parking. Also, during the simulation, it was determined that the biggest speed is under parallel parking to the sidewalk and is $28.22 \mathrm{~km} / \mathrm{h}$, and without parking, in these conditions, the speed is $30.14 \mathrm{~km} / \mathrm{h}$.

Simulation of the determination of traffic delay, and also queue length in the existing conditions and without parking under the different ways of parking was carried out. For the comparison of the existing movement conditions (parking is present), and also without parking, we changed the built simulation model with the change of the roadway width (increase of the number of lanes). Simulation results are given in Table 5.

Table 5

Simulation results of traffic delay determination with and without parking

\begin{tabular}{|c|c|c|c|c|c|c|c|}
\hline \multirow{2}{*}{$\begin{array}{l}\text { Ways of parking } \\
\text { near the sidewalk }\end{array}$} & \multirow{2}{*}{$\begin{array}{l}\text { Average } \\
\text { traffic } \\
\text { intensity } \\
\text { per hour, } \\
\text { pcu/h }\end{array}$} & \multicolumn{2}{|c|}{$\begin{array}{c}\text { Average traffic delay, } \\
\text { sec/auto }\end{array}$} & \multicolumn{2}{|c|}{ Average queue length, $\mathrm{m}$} & \multicolumn{2}{|c|}{$\begin{array}{l}\text { Maximal queue } \\
\text { length, } \mathrm{m}\end{array}$} \\
\hline & & $\begin{array}{l}\text { existing } \\
\text { movement } \\
\text { conditions }\end{array}$ & $\begin{array}{l}\text { without } \\
\text { parking }\end{array}$ & $\begin{array}{l}\text { existing } \\
\text { movement } \\
\text { conditions }\end{array}$ & $\begin{array}{l}\text { without } \\
\text { parking }\end{array}$ & $\begin{array}{l}\text { existing } \\
\text { movement } \\
\text { conditions }\end{array}$ & $\begin{array}{l}\text { without } \\
\text { parking }\end{array}$ \\
\hline $\begin{array}{c}\text { Parallel to the } \\
\text { sidewalk }\end{array}$ & 1008 & 12.56 & 11.73 & 25.63 & 17.15 & 185.64 & 124.24 \\
\hline $\begin{array}{l}\text { Under the angle of } \\
30^{\circ} \text { to the sidewalk }\end{array}$ & 1636 & 12.78 & 10.23 & 31.26 & 21.39 & 197.17 & 119.22 \\
\hline $\begin{array}{l}\text { Under the angle of } \\
45^{\circ} \text { to the sidewalk }\end{array}$ & 1690 & 13.77 & 10.06 & 30.55 & 21.08 & 226.35 & 95.65 \\
\hline $\begin{array}{l}\text { Under the angle of } \\
60^{\circ} \text { to the sidewalk }\end{array}$ & 1482 & 18.22 & 7.55 & 38.17 & 18.91 & 266.33 & 93.67 \\
\hline $\begin{array}{l}\text { Under the angle of } \\
90^{\circ} \text { to the sidewalk }\end{array}$ & 1636 & 19.26 & 7.03 & 42.11 & 17.38 & 270.18 & 71.63 \\
\hline
\end{tabular}

A graphical representation of the comparative results of the simulation of the change of traffic delays, the average and the maximal queue length with and without parking are given in Fig. 3-5. 


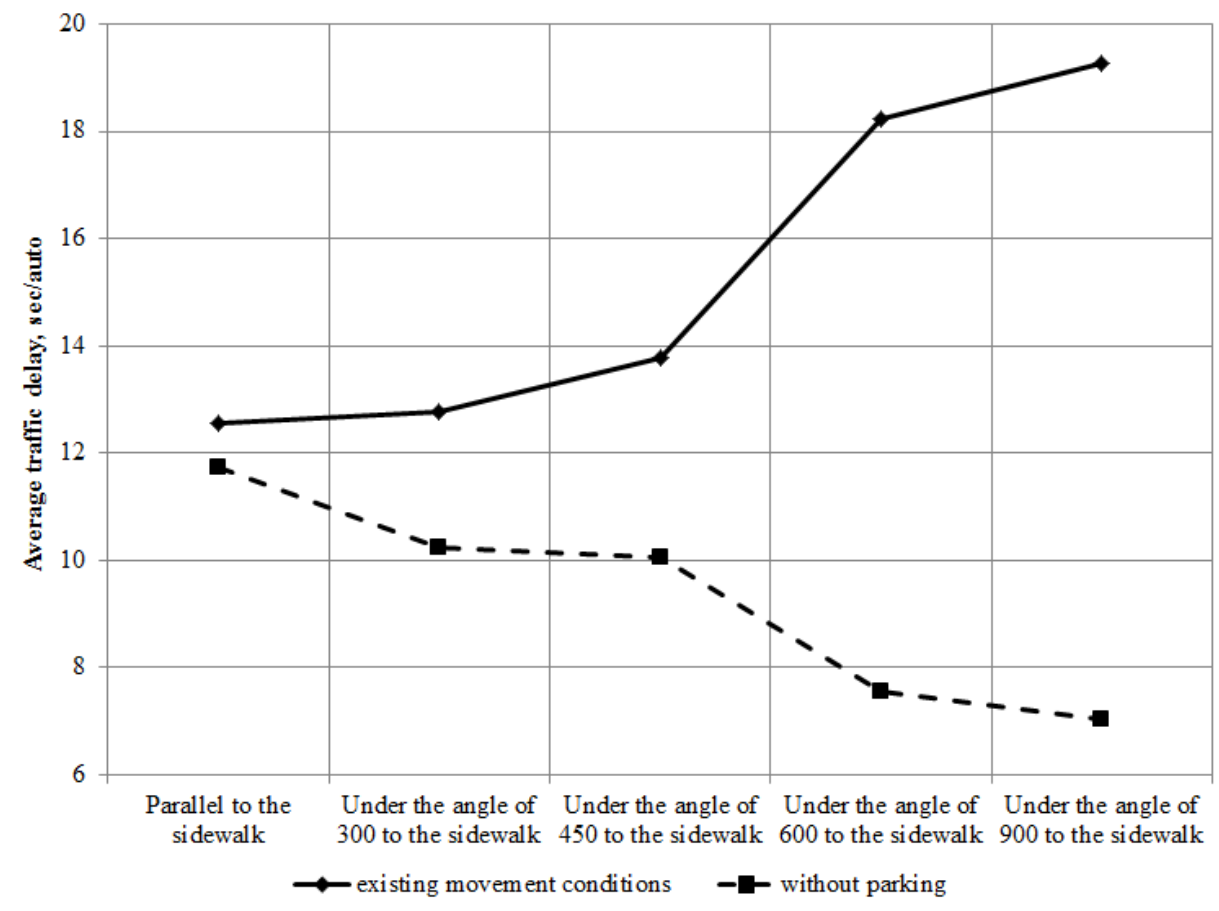

Fig. 3. Graph of the change of the average traffic delay with and without parking

Analyzing Fig. 3, we can tell that the average delay without parking parallel to the sidewalk decreases by $7 \%$; under the angle of $30^{\circ}$ to the sidewalk - by $20 \%$; under the angle of $45^{\circ}$ to the sidewalk - by $27 \%$; under the angle of $60^{\circ}$ to the sidewalk - by $59 \%$; under the angle of $90^{\circ}$ to the sidewalk - by $63 \%$;

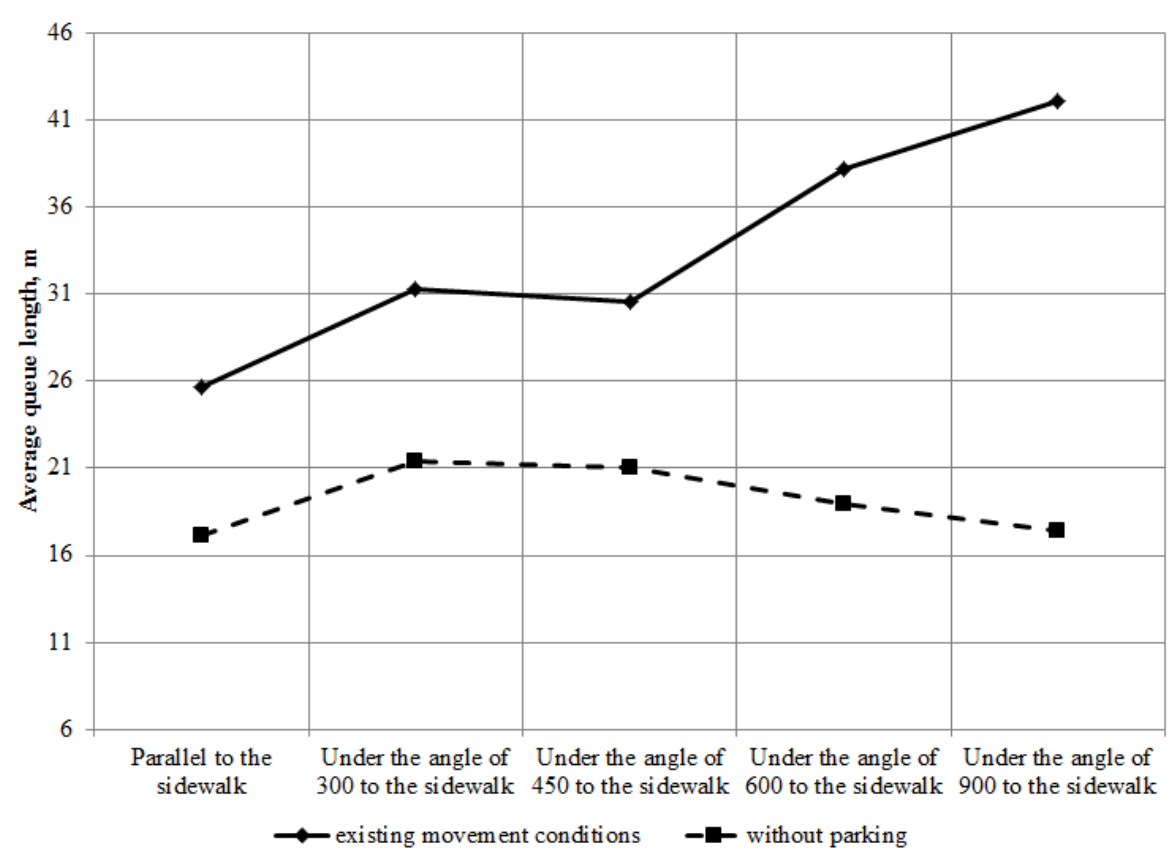

Fig. 4. Graph of the change of the average queue length with and without parking

Comparing the average and maximum queue length (Fig. 4 and 5), we can see the linear dependence to the decrease of the queue length without parking. The greatest decrease is observed when parking to the sidewalk at an angle of $90^{\circ}$, the average queue length is $17.28 \mathrm{~m}$, the maximum $-71.63 \mathrm{~m}$.

Therefore, when justifying the expediency (or restriction) of street parking, it is necessary to take into account not only traffic delay but also parking duration. 


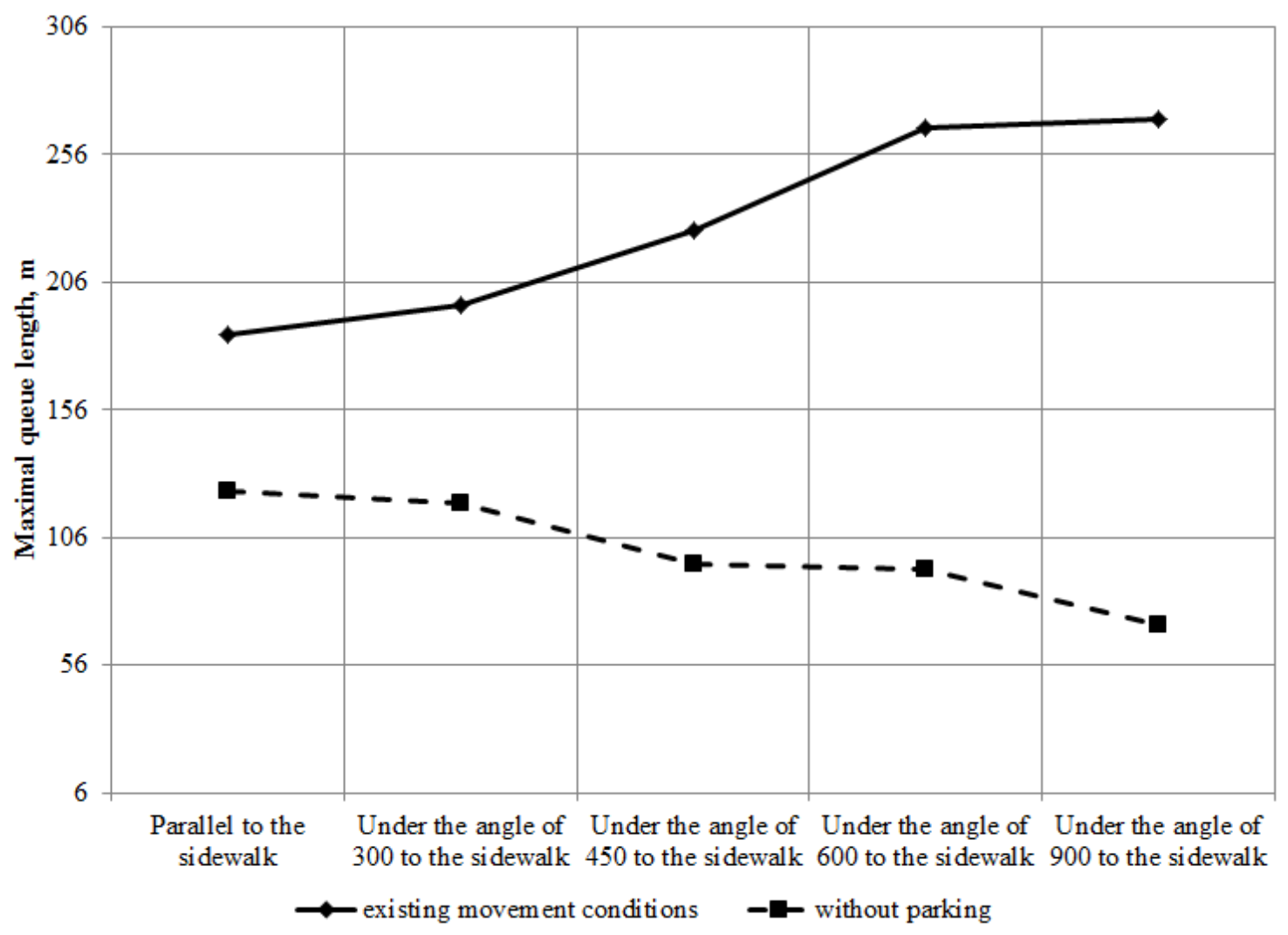

Fig. 5. Graph of the change of the maximum queue length with and without parking

To study the impact of street parking duration on the average speed of traffic flow and its delays, simulation modeling in the PTV VISSIM software was used.

The technique of simulation:

1. A length of $375 \mathrm{~m}$ was constructed (one-way traffic, number of lanes -2 , lane width $-3.75 \mathrm{~m}$ ).

2. Mixed traffic flow with the share of cars of $80 \%$ was created. Besides, the value of the desired speed of the vehicle is appropriate to the vehicle of such types: for cars $-45 \mathrm{~km} / \mathrm{h}$; for trucks $-30 \mathrm{~km} / \mathrm{h}$; for buses $-25 \mathrm{~km} / \mathrm{h}$.

3. To investigate the impact of the parking on the average speed of traffic flow and its delays, the entrance flow was given by the intensity of 1000 auto/h.

4. On the right lane (beginning from $100 \mathrm{~m}$ of the segment), a parking with the number of parking lots of 25 and the length of one parking lot of $6 \mathrm{~m}$ was created.

5 . The route of pulling into the parking only for cars was created.

6. The duration of parking is $300 \mathrm{sec}, 600 \mathrm{sec}, 900 \mathrm{sec}, 1200 \mathrm{sec}, 1500 \mathrm{sec}$, and $1800 \mathrm{sec}$.

7. On the left lane, every $25 \mathrm{~m}$ measurement points were established.

8. In the regime of the normal startup for one cycle, for the different parking duration, the simulation of the network section with parking was carried out (share of cars that pull into the parking is $75 \%$ ).

Research results of the impact of parking duration (parallel to the sidewalk) is given in Fig. 6.

Analyzing Fig. 6, we can say that the less the average parking duration, the less movement speed is on the neighbor (left) lane. So, for the parking duration of $300 \mathrm{sec}$, in the middle of the parking zone $(175 \mathrm{~m})$, the least traffic flow speed is observed $-14.75 \mathrm{~km} / \mathrm{h}$. It can be explained by the fact that vehicles on the left lane have to slow down more frequently to allow cars to pull out of the parking. After passing the parking zone, the increase in traffic flow speed is observed. The biggest speed value is with parking duration of $1800 \mathrm{sec}$ as the impact of parked vehicles in such conditions is not significant.

The average traffic delay should be taken into account when investigating traffic conditions to limit the duration of parking (Fig. 7). 


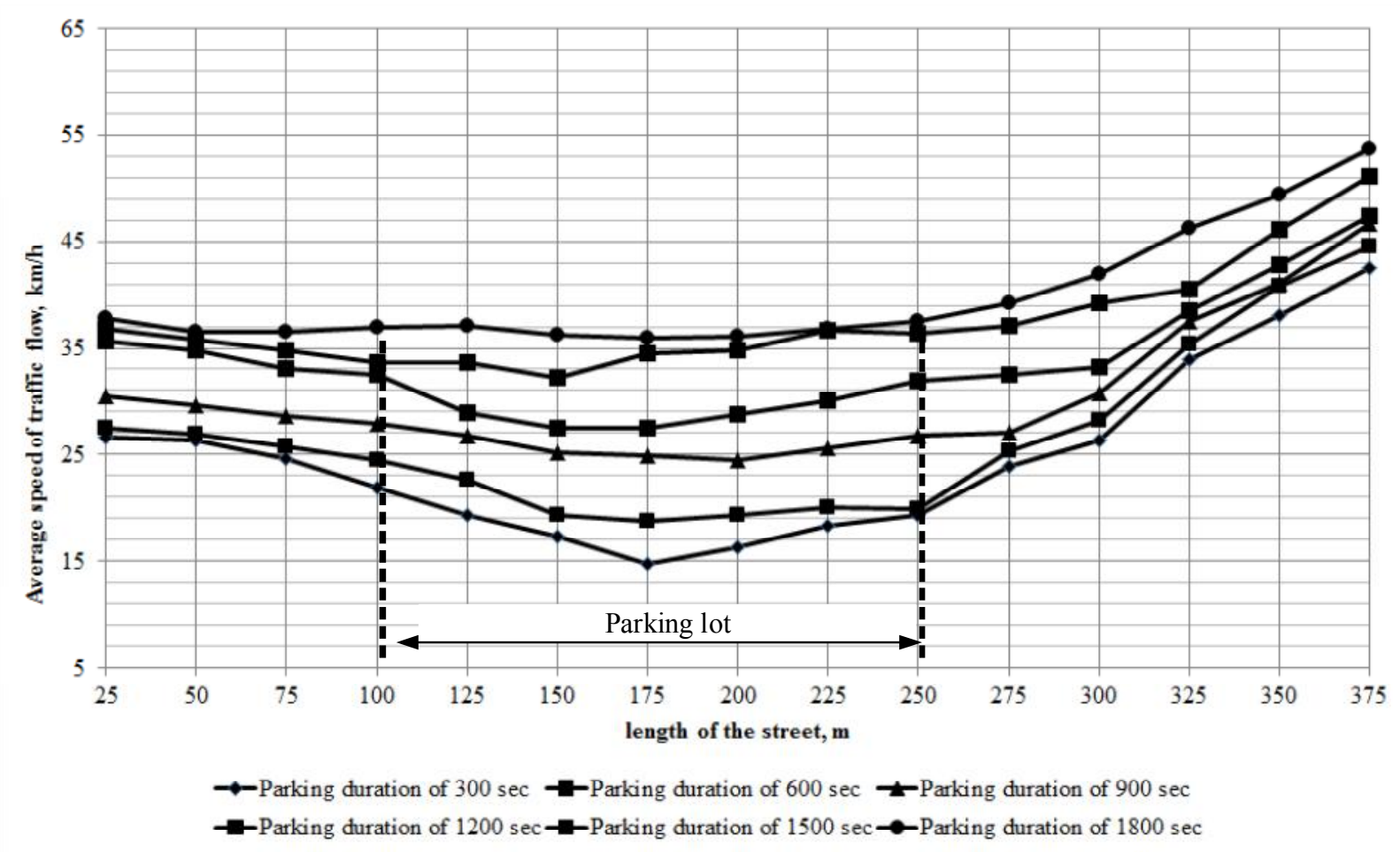

Fig. 6. Graph of the change of traffic flow speed on the left lane through the network section length from the parking duration

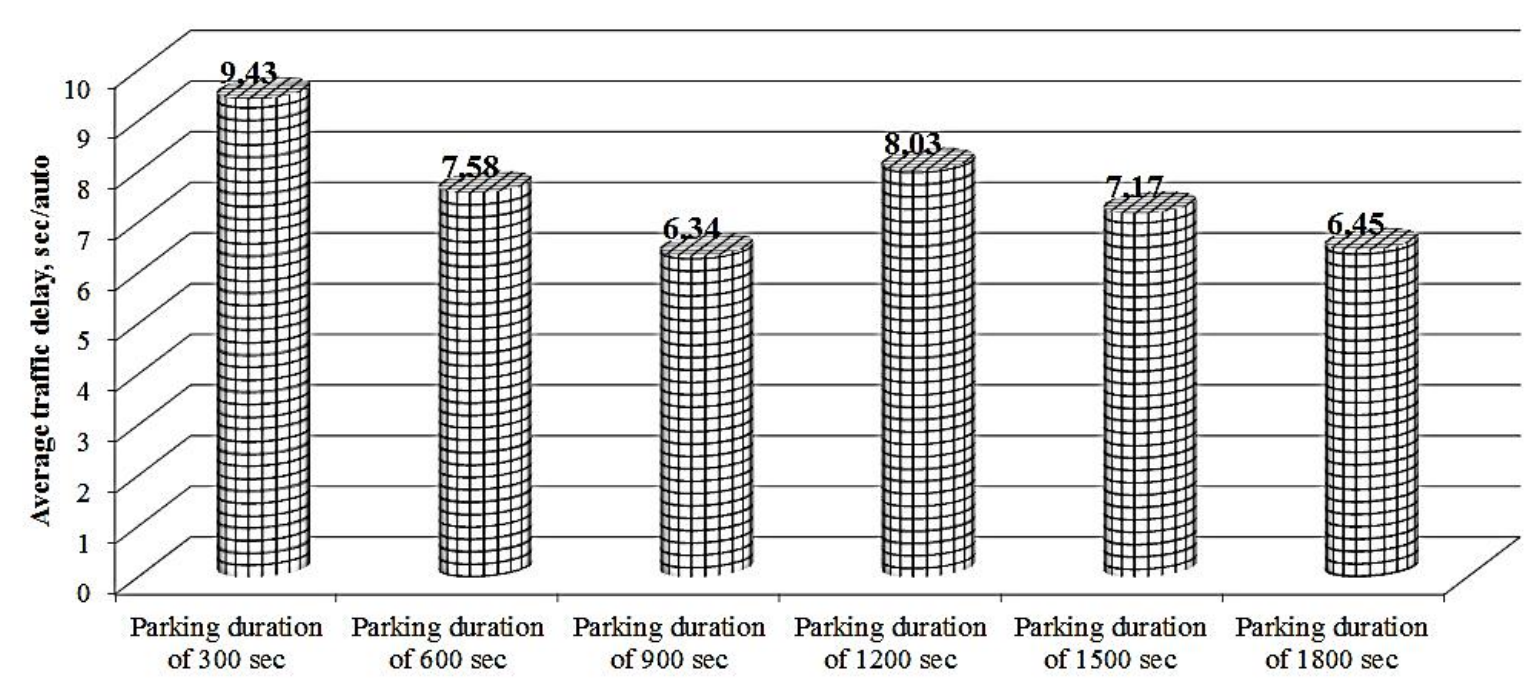

Fig. 7. Graph of the change of traffic flow speed on the left lane through the network section length from the parking duration

The average traffic delay has the least values with the parking duration of 900 and $1800 \mathrm{sec}$ and it is respectively 6,34, and 6,45 sec/auto, the biggest values with the duration of $300 \mathrm{sec}$ on the right lane and is $9.43 \mathrm{sec} /$ auto.

\section{CONCLUSIONS AND RESEARCH PERSPECTIVES}

Therefore, when modeling the impact of street parking on traffic flow delays using program software PTV VISSIM, it was established that during the design of street parking parallel to the sidewalk it is necessary to implement restrictions to the parking duration to increase the road network capacity and traffic flow speed. 
The aim of further scientific research in this area is to develop recommendations about the parking limitations under which the optimal traffic flow conditions and high efficiency of transport service will be achieved.

\section{References}

1. Polischuk, V. P., Zagoruy, O. O. (2004). To the question about car parking. Do pitannya schodo parkuvannya avtomobiliv (pp. 175-180). - Kyiv: Tehnika (in Ukrainian).

2. Rao1, A. M., Rao1, K. R. (2012). Measuring urban traffic congestion - a review. International Journal for Trafficc and Transport Engineering, Volume 2(4). 286-305 (in English)

3. Knote, T. (2011). The Determination of Conflicting Flow Rates for the Calculation of Capacities of Minor Traffic Streams on Priority Intersections. Procedia Social and Behavioral Sciences, Volume 16. 642-652 (in English)

4. Prasetijo, J., Pour, M.H., Ghadiri, S.M. (2011). Capacity of Unsignalized Intersections under Mixed Traffic Conditions. Procedia Social and Behavioral Sciences, Volume 16. 676-685 (in English)

5. Zagoruy, O. O. (2007). Impact of parked vehicles on street network capacity. Candidate's thesis. Kyiv: NTU (in Ukrainian).

6. Stel'mah, O.V (2004). City planning principles and methods of formation the system of private cars parking in big and large cities of Ukraine (on example of Kyiv city). Candidate's thesis. Kyiv: KNUBA (in Ukrainian).

7. Fornalchik, E. Yu., Bilous, A. B., Mogila, I. A. (2012). Impact of on-street parking on the running way capacity and the average velocity of traffic flow. Vpliv vulichnih stoyanok na propusknu zdatnist proyiznoyi chastini ta serednyu shvidkist transportnogo potoku, Volume 2, 47-53 [in Ukrainian].

8. Lobashov, O.O. (2010). Modelyuvannya vplivu merezhi parkuvannya na transportni potoki u mistah [Modelling the impact of parking network on traffic flows in cities]. Kharkiv: HNAMG (in Ukrainian).

9. Gavrilov, E. V., Dmitrichenko, M. F., Dolya,V. K., Lanoviy, O. T., Linnik, I. E., Polischuk, V. P. (2005). Fundamentals of the theory of systems and control. Kyiv: ZNANNJA UKRAJINY (in Ukrainian).

10. Vasyl'jeva, G. Ju. (2007). Minimization methods of traffic delays on the arterial street network of Ukrainian cities. Candidate's thesis. Kyiv: KNUBA (in Ukrainian).

11. Klementschitz, R., Grass, P. (2019). The effects of a new park and ride facility supply in the city of Vienna, Austria. WIT Transactions on The Built Environment, Volume 186. 11-21. doi: 10.2495/UT190021 (in English)

12. Ismiyati, I., Wicaksono, Y.W., Riyanto, B., \& Parulian R. (2018). Control of urban parking based on zoning rates in the context of sustainable transportation. MATEC Web of Conferences, Volume 195. 1-10. doi: 10.1051/matecconf/201819504020 (in English)

13. Madhu, K.A., Rajakumara, H.N. (2019). Effect of Improper Bus Stop Locations on Capacity and SpeedFlow Relations on Urban Roads. International Journal of Recent Technology and Engineering, Volume 8. 14891494. doi: 10.35940/ijrte.C4148.098319 (in English)

14. Putra, R., Hidayah, R. (2019). The Effects of On-Street Parking Toward Street Performance (Case Study: Kaliurang Street, Yogyakarta, Indonesia). International Conference on Sustainable Insfrastructure, Volume 366. 1-10. doi: 10.1088/1755-1315/366/1/012026 (in English)

15. Geistefeldt1, J. (2011). Capacity effects of variable speed limits on German freeways. Procedia Social and Behavioral Sciences, Volume 16. 48-56 (in English)

16. Koohpayma, J., Tahooni, A., Jelokhani-Niaraki, M., \& Arsanjani J. J. (2019). Spatial Analysis of CurbPark Violations and Their Relationship with Points of Interest: A Case Study of Tehran, Iran. Sustainability, Volume 11. 1-15 (in English)

17. Sulistyono, S., Sulistio, H., Djakfar, L., \& Badriani R.E. (2018). On street parking and its impact on road performance. MATEC Web of Conferences, Volume 181. 1-8. doi: 10.1051/matecconf/201818106008 (in English)

18. Khaliq, A., Waerden, P., Djakfar, L., \& Wets G. (2019). A Conceptual Framework for Forecasting Car Driver's On-Street Parking Decisions. Transportation Research Procedia, Volume 37. 131-138 (in English)

19. Carlos, A., Toledo, M. (2011). Congestion Indicators and Congestion Impacts: A Study on the Relevance of Area-wide Indicators. Procedia Social and Behavioral Sciences, Volume 16. 781-791 (in English)

Received 28.02.2020; Accepted in revised form 25.03.2020. 